\title{
Soil Sampling Techniques for Determining the Effect of Cultural Practices on Rhizoctonia oryzae-sativae Inoculum in Rice Field Soils
}

\author{
Thomas C. Miller and Robert K. Webster, Department of Plant Pathology, University of California, Davis 95616
}

\begin{abstract}
Miller, T. C., and Webster, R. K. 2001. Soil sampling techniques for determining the effect of cultural practices on Rhizoctonia oryzae-sativae inoculum in rice field soils. Plant Dis. 85:967972.

Methods were evaluated to quantify sclerotia in rice fields affected with aggregate sheath spot disease. Recovered sclerotia were compared with disease ratings at harvest for paddies subjected to various postharvest cultural straw management practices. Sclerotial inoculum level was not always correlated with subsequent disease incidence in rice aggregate sheath spot disease, suggesting alternative sources of inoculum and other factors influencing disease development. Straw management practices affected the inoculum load of Rhizoctonia oryzae-sativae, as determined by methods recovering sclerotia from California rice field soil samples. Traditional wet sieving of soil samples was improved using a potassium carbonate solution to float heavier sclerotia that normally remained in the sediment. The relationship of inoculum in the soil from seedbeds and the incidence of resulting disease measured just before harvest was investigated over 3 years at three sites. A linear dose-response was found at only one site where the number of floating sclerotia was more strongly correlated with disease incidence than total number of sclerotia (floating plus nonfloating sclerotia). Floating sclerotia were more easily counted using a water floatation extraction (WFE) than were total sclerotia by using a potassium carbonate floatation extraction (PCFE) or a combination of the two assays (WFE + PCFE), and the WFE more accurately predicted disease incidence than did either PCFE or WFE + PCFE. All assays detected significant differences between inoculum levels as influenced by various straw residue management practices, with removal of straw residue significantly reducing number of soilborne sclerotia.
\end{abstract}

Rhizoctonia oryzae-sativae (Sawada) Mordue, (Ceratobasidium oryzae-sativae Gunnell \& Webster) causes aggregate sheath spot of rice (Oryzae spp.) in California $(9,10)$. All currently grown public varieties of rice in California are susceptible to some degree. Disease symptoms occur on the leaves and sheaths as ovalshaped lesions, green, gray, or tan at center, surrounded by a thin brown-to-black border, and often have a thin, vertical, necrotic line spanning the center from top to bottom. As the infection spreads, darkened bands appear radiating outward from this lesion in concentric fashion, giving the appearance of aggregations of lesions. Infection can involve the panicle, resulting in discolored grain. Sclerotia can form inside the hollow leaf spaces of lower leaf blades and sheaths and on the surface of the infected tissue. Sclerotia persist in the soil or associated with crop residue. Later, the next rice crop is infected by sclerotia floating on the paddy water, or possibly through root infection (25). An informal survey in 1994 noted the disease through-

Corresponding author: Thomas C. Miller

E-mail: millert@naturechem.org

Accepted for publication 10 May 2001.

Publication no. D-2001-0717-03R

(C) 2001 The American Phytopathological Society out California rice culture, but the incidence of disease was erratic; detected in some paddies but not those immediately adjacent on the same farm (T. C. Miller and R. K. Webster, unpublished).

Aggregate sheath spot disease is predominantly monocyclic. This suggests that the number of sclerotia in the seedbed (primary inoculum) should affect disease incidence in the subsequent rice crop, as has been demonstrated for other sclerotial pathogens of rice (37). An accurate method to estimate primary inoculum in the seedbed would promote studies on disease epidemiology and the development of effective management strategies. To be useful, such a method should provide unambiguous identification of $R$. oryzae-sativae based on physical characteristics and confirm viability of sclerotia. Ideally, such a method should also enable the detection of other sclerotial fungi present as well. However, preliminary experiments showed morphological and physical characteristics of sclerotia (variation in shape, size, and density) complicated their recovery and confounded the identification from soil (22).

Methods reported to determine soil inoculum levels of other sclerotial plant pathogens include baiting techniques using suitable hosts, and soil sieving to recover sclerotia or hyphal fragments (29). Retrieval of sclerotia or hyphae from soil can be further divided by use of selective me- dia $(7,19,31,35)$, mechanical separation of propagules $(2,5,21,28,34,38)$, or combinations of the two $(4,16)$. Other methods have employed flotation using density gradient solutions containing sucrose, molasses, cesium chloride, hydrogen peroxide, chloroform, or potassium carbonate to improve recovery $(1,27,32,33)$, and potassium carbonate solutions have also been used to separate seed from soil (3).

The objectives of this research were to develop a reliable method to quantify sclerotia of Rhizoctonia oryzae-sativae from rice soils and then determine the effect of rice straw residue management on sclerotial inoculum levels in the seedbed. Partial results were presented previously (23).

\section{MATERIALS AND METHODS}

Preliminary results were used to design a soil assay for sclerotia of Rhizoctonia oryzae-sativae based on (i) sclerotial sizes (360 to $1,250 \mu \mathrm{m} \times 270$ to $620 \mu \mathrm{m}, 1 \times \mathrm{w}$, within rice tissue and larger when recovered from the surface of rice straw residue or artificial media); (ii) sclerotial shapes ranging from spheroidal to cylindrical from within rice tissues to irregular for sclerotia produced externally; (iii) the maximum density of sclerotia $\left(\rho=1.42 \mathrm{~g} \cdot \mathrm{ml}^{-1}\right)$; (iv) the time required (approximately $4.5 \mathrm{~h}$ ) for sclerotia to float or sink in water; (v) viability of floating sclerotia and those from the sediment; (vi) toxicity of exposure of sclerotia to concentrated solutions of $\mathrm{K}_{2} \mathrm{CO}_{3}(a q)$; (vii) disinfection of sclerotia; and (viii) media to culture the pathogen for positive identification (22).

Recovery of Rhizoctonia oryzae-sativae sclerotia from soil using $\mathrm{H}_{2} \mathrm{O}$ (WFE) and $\mathrm{K}_{2} \mathrm{CO}_{3}(a q)$ extraction (PCFE). Soil samples were flooded for $24 \mathrm{~h}$, then the floating debris was wet sieved (60 mesh) (Water Flotation Extraction, or WFE). Debris was inspected under a dissecting scope after air drying and hand-picked sclerotia were surface sterilized $30 \mathrm{~s}$ in $8 \%$ bleach, incubated on water agar (WA) plates amended with $100 \mathrm{ppm}$ chlorotetracycline, then maintained at $25^{\circ} \mathrm{C}$ under daytime fluorescent lights. After 2 to 10 days the margins of putative $R$. oryzae-sativae colonies were transferred to corn meal agar (CMA) plates for positive identification based on formation of diagnostic sclerotia. For plates on which new sclerotia did not form, colony margins from CMA were transferred to potato dextrose agar (PDA), which consistently encouraged sclerotial production. One to $3 \%$ of sclerotia recovered from rice soils failed to form new 
sclerotia on CMA. However, CMA slowed the spread of contaminating fungi, thus allowing more consistent isolation of $R$. oryzae-sativae in initial transfers.

Based on the most dense sclerotia found in field collections or laboratory cultures $\left(\rho=1.42 \mathrm{~g} \cdot \mathrm{ml}^{-1}\right)$, a $\mathrm{K}_{2} \mathrm{CO}_{3}(a q)$ solution adjusted to a density of $\rho=1.50 \mathrm{~g} \cdot \mathrm{ml}^{-1}$ was used to float all remaining sclerotia from the soil samples. Soil samples were wet sieved (60 mesh) and the recovered debris air-dried. The debris was placed in $\mathrm{K}_{2} \mathrm{CO}_{3}(a q)$ solution and sclerotia were collected from the surface by vacuum filtration into a second vessel. To minimize toxic exposure due to extreme alkalinity of the $\mathrm{K}_{2} \mathrm{CO}_{3}(a q)$ solution $(\mathrm{pH}>13)$ the second vessel contained acidified water (approximately 5 to $10 \% \mathrm{vol} / \mathrm{vol}$ concentrated $\mathrm{H}_{2} \mathrm{SO}_{4}$ ) with bromothymol blue indicator to note when neutrality had been achieved. A highly acidified solution had to be used to neutralize all the $\mathrm{K}_{2} \mathrm{CO}_{3}(a q)$ associated with collected sclerotia. Sclerotia were exposed to $\mathrm{K}_{2} \mathrm{CO}_{3}(a q)$ only about $3 \mathrm{~min}$, which reduced toxicity as measured by germinability (22). After the potassium carbonate flotation extraction (PCFE), sclerotia were cultured as before for identification.

The efficacy of recovery was tested by amending clean soil with known levels of $R$. oryzae-sativae sclerotia (Table 1). Laboratory-produced sclerotia (20) and sclerotia collected from California rice fields in Sutter and Butte counties were used. Soil used in these tests included nonsterilized rice soil (Colusa Co., aggregate sheath spot low incidence) and steamed greenhouse soil (Yolo sandy clay loam and sand in a 5:1 ratio). Sclerotia were mixed with these soil at proportions ranging from 1 sclerotia per $300 \mathrm{~g}$ of soil to 1 sclerotia per $\mathrm{g}$ of soil (Table 1). Each sample or subsample of amended soil provided observations of the numbers of sclerotia recovered by WFE and the additional number recovered from the sediment by PCFE. This sequential procedure allowed higher germination as fewer sclerotia were exposed to the toxic $\mathrm{K}_{2} \mathrm{CO}_{3}(a q)$ solution. Recovered sclerotia were cultured for positive identification. Each determination of sclerotia per $\mathrm{g}$ of soil was from 2 to 6 subsamples of 2 replications of amended soil per infestation level (Table 1).

Field soil sampling and description of experimental design in disease management experiments. Soil sampling. Each field site was sampled after final seedbed preparation, but before the fields were flooded. Within each rice flood basin, soil samples from the top $2.5 \mathrm{~cm}$ of the soil were collected at 15 to 20 stops along a Wshaped path. Bulked samples were placed in paper bags, air-dried in the laboratory, and subsampled for inoculum assay after pulverizing by a single passage through either a meat or a soil grinder. Site 1 (Sutter County, CA) was sampled in 1993 and 1994 with one bulked sample per flood basin across the 30 flood basins of approximately 0.2 hectares each; Site 2 (Colusa County, CA) was sampled with 3 bulked subsamples (W-shaped paths covering approximately $0.23 \mathrm{ha}$ ) per flood basin (cultural treatment experimental unit) from 11 and 5 basins of approximately 0.7 ha each in 1994 and 1995 respectively; and site 3 (Butte Co., CA) was sampled in 1995 with 2 bulked subsamples (W-shaped paths covering approximately $0.095 \mathrm{ha}$ ) per basin across the 32 flood basins (cultural treatment experimental unit) of approximately 0.19 ha each. More intensive subsampling was performed at this site due to the extreme length of the experimental treatment units with respect to their width.
Sample size and extraction methods are listed in Table 2.

Straw management methods. Site 1: Straw management practices consisted of fall burning of residue, fall incorporation of residue, and spring incorporation of residue (37), either with or without a winter cover crop of vetch. This commercial site had sandier soil (Marcum clay loam) than the other sites. This trial was sampled during the fourth and fifth years of continuous straw management experiments (i.e., the postharvest cultural practices were repeated annually for each basin). Treatments were arranged in a split plot design using 5 replications, main plots being straw management and subplots being cover crop.

Site 2: This site was established in a commercial rice field during the fall of 1993. Treatments included burning, rolling, baling and removing, and incorporating straw in the fall after harvest with or without winter flooding, and were arranged in a split plot design using 4 replications. Main plots were winter flooding and subplots were the straw management practices. The soil (Willows Clay) was typical of soils in rice acreage on the western side of the Sacramento Valley. This site was also established to examine the long-term effects of repeated annual straw management practices.

Site 3: This site had the same experimental design as site 2, but was established on Stockton clay adobe soil at the rice research experimental station near Biggs, CA.

Disease evaluation. Disease incidence was evaluated just before harvest. Rice tillers were collected by following similar W-shaped paths traveled when collecting soil. Rice tillers (5 to 10 ) were cut just above the soil from draining or dried pad-

Table 1. Recovery of Rhizoctonia oryzae-sativae sclerotia from soils to which known numbers of sclerotia were added

\begin{tabular}{|c|c|c|c|c|c|c|c|}
\hline \multirow[b]{3}{*}{ Sclerotia per gram soil ${ }^{\mathrm{a}}$} & \multirow[b]{3}{*}{ Extraction fraction $^{\mathbf{b}}$} & \multicolumn{4}{|c|}{ Field soil } & \multirow{2}{*}{\multicolumn{2}{|c|}{$\begin{array}{c}\text { Sterile soil } \\
\text { Sclerotia from field }^{\mathrm{e}}\end{array}$}} \\
\hline & & \multicolumn{2}{|c|}{ Sclerotia from culture } & \multicolumn{2}{|c|}{ Sclerotia from field ${ }^{\mathbf{d}}$} & & \\
\hline & & \% Recovery & $\%$ Viable & \% Recovery & $\%$ Viable & \% Recovery & \% Viable \\
\hline 0.0067 & $\begin{array}{c}\mathrm{H}_{2} \mathrm{O} \\
\mathrm{K}_{2} \mathrm{CO}_{3} \\
\text { Total }\end{array}$ & $\begin{array}{l}\ldots \\
\cdots \\
\cdots\end{array}$ & $\begin{array}{l}\cdots \\
\cdots \\
\cdots\end{array}$ & $\begin{array}{l}\cdots \\
\cdots \\
\cdots\end{array}$ & $\begin{array}{l}\cdots \\
\cdots \\
\cdots\end{array}$ & $\begin{array}{c}0 \\
100 \\
100\end{array}$ & $\begin{array}{c}0 \\
50 \\
50\end{array}$ \\
\hline 0.010 & $\begin{array}{c}\mathrm{H}_{2} \mathrm{O} \\
\mathrm{K}_{2} \mathrm{CO}_{3} \\
\text { Total }\end{array}$ & $\begin{array}{c}50 \\
50 \\
100\end{array}$ & $\begin{array}{c}0 \\
100 \\
50\end{array}$ & $\begin{array}{c}50 \\
50 \\
100\end{array}$ & $\begin{array}{l}100 \\
100 \\
100\end{array}$ & $\begin{array}{l}\ldots \\
\cdots \\
\cdots\end{array}$ & $\begin{array}{l}-- \\
-- \\
--\end{array}$ \\
\hline 0.10 & $\begin{array}{c}\mathrm{H}_{2} \mathrm{O} \\
\mathrm{K}_{2} \mathrm{CO}_{3} \\
\text { Total }\end{array}$ & $\begin{array}{l}40 \\
45 \\
85\end{array}$ & $\begin{array}{l}75 \\
56 \\
65\end{array}$ & $\begin{array}{c}5 \\
85 \\
90\end{array}$ & $\begin{array}{l}100 \\
41 \\
44\end{array}$ & $\begin{array}{c}20 \\
90 \\
100\end{array}$ & $\begin{array}{l}33 \\
11 \\
17\end{array}$ \\
\hline 1.0 & $\begin{array}{l}\mathrm{H}_{2} \mathrm{O} \\
\mathrm{K}_{2} \mathrm{CO}_{3} \\
\text { Total }\end{array}$ & $\begin{array}{l}42 \\
50 \\
92\end{array}$ & $\begin{array}{l}83 \\
67 \\
75\end{array}$ & $\begin{array}{l}22 \\
72 \\
94\end{array}$ & $\begin{array}{l}91 \\
65 \\
71\end{array}$ & $\begin{array}{l}16 \\
82 \\
98\end{array}$ & $\begin{array}{l}55 \\
44 \\
46\end{array}$ \\
\hline
\end{tabular}

${ }^{a}$ Known from numbers of sclerotia added.

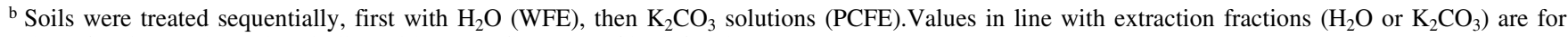
those fractions only. Values in line with total reflect sum of both fractions.

${ }^{c}$ Sclerotia produced on rice hull mixture, which normally germinate totally $(100 \%)$ on WA. Soil from rice field where disease incidence was insignificant, and sclerotial inoculum undetectable. Values are means of 2 replicate $100 \mathrm{~g}$ soil samples (soil $=200 \mathrm{~g}$ per infestation level tested).

${ }^{\mathrm{d}}$ Field sclerotia introduced to field soil described above. Values are means of 2 replicate $100 \mathrm{~g}$ soil samples (soil $=200 \mathrm{~g}$ per infestation level tested).

e Field sclerotia introduced to greenhouse soil. Values are means of 6 replicate subsamples $(50 \mathrm{~g}$ each $)$ comprising a total of two $150 \mathrm{~g}$ soil samples $($ soil $=$ $300 \mathrm{~g}$ per infestation level tested). 
dies at 15 to 20 stops along the paths and bulked. There was one bulked sample per basin for site 1, three bulked subsamples per basin for site 2, and two bulked subsamples per basin for site 3, to correspond to the soil samples. For all samples (site 1) or subsamples (sites 2 and 3), >100 headed tillers were rated. Tillers with symptoms characteristic of aggregate sheath spot disease (see above and 36) and/or sclerotia embedded in the tissue were considered diseased.

Data analysis. Analysis of variance was used to determine the effects of treatments on disease development and number of sclerotia per $\mathrm{g}$ of soil. Correlation analysis was used to determine relationships between disease incidence at harvest and sclerotia per $g$ of soil in the seedbed for respective crop years. Mean separation between treatments was determined by least significant difference using a synthetic $\mathrm{t}\left(\mathrm{t}^{\prime}\right)$ value for hypothesis testing according to Steel and Torrie (30) for split plot ANOVA. All calculations were performed using Excel software (Microsoft, versions 4 to 6 , on Macintosh hardware).

\section{RESULTS}

Method validation. Neither soil type nor sclerotial source affected percentage recovery in soil recovery efficacy tests, but sclerotia from site 1 (Sutter County) placed in sterilized greenhouse soil had the lowest overall viability (Table 1). Recovery of laboratory-produced sclerotia in field soil was $85 \%$ using combined WFE and PCFE, but not all recovered sclerotia germinated due to reduced viability. At least $90 \%$ of sclerotia were recovered in eight of nine attempts ( 3 trials times 3 infestation levels) using both extractions, and all sclerotia were recovered in four of nine trials (Table 1). Variation in the fraction of sclerotia that floated upon water was high, as was found previously (22). Even within samples (i.e., between subsamples) the number of sclerotia floating on water was not constant despite the same source of sclerotia.

Identification of this fungus based upon visual examination of sclerotia is unreliable, so confirmation by culturing was required to verify recovery. This method relied on living sclerotia to provide positive and reliable identification.

Field soil inoculum assay and disease evaluation. Site 1 (Sutter County, CA), 1993: A significant correlation between straw management practices and incidence of aggregate sheath spot disease or number of sclerotia recovered was detected (Table 2). Only main plot (straw management) effect was significant. The lowest disease level was observed in fields that had been burned (52\% aggregate sheath spot incidence). The greatest disease incidence occurred where the rice stubble had not been incorporated into the soil until the following spring ( $80 \%$ incidence), and an intermediate amount of disease was observed with fall incorporation $(68 \%$ incidence). The vetch winter cover crop had no effect on measured inoculum levels nor disease incidence, although an interaction of main and subplot effects was detected upon disease incidence in 1993. This interaction was not detected the following season in 1994 (22).

At this site, total sclerotia (recovered by WFE) were not correlated to disease inci- dence $(r=0.23, \mathrm{n}=30)$, but a significant correlation $(r=0.56, P<0.01$, Table 2$)$ was detected between disease and the subset of viable sclerotia. When data were combined by straw management practice (i.e., 6 treatments of 5 replications each), the correlations of extractable fractions to observed disease were more pronounced (Table 2). PCFE recovered more sclerotia of $R$. oryzae-sativae per $\mathrm{g}$ of soil than WFE for most basins in 1993 (22). However, the number of viable sclerotia recovered by WFE was greater than the number of viable sclerotia recovered by PCFE, probably due to the toxicity of the $\mathrm{K}_{2} \mathrm{CO}_{3}(a q)$.

At this site, in 1993, analysis of paddies without consideration of treatment $(n=30)$ showed the greatest linear correlation of disease incidence to viable sclerotia that floated on water (Table 2). However, grouping the paddies by cultural practice ( 6 means of 5 replications each versus 30 means) showed greatest correlation of disease incidence to the total number of floating sclerotia (i.e., viable and nonviable, Table 2). These fitted lines' intercepts suggested that measurable disease would occur without detection of sclerotial inoculum from soil, but sclerotia were recovered from each flood basin's soil samples.

Site 1 (Sutter Co., CA) 1994: The counts of sclerotia recovered by WFE applied to a sampling of 10 basins showed significant correlation to disease incidence for both the total sclerotia recovered and the viable sclerotia per $\mathrm{g}$ of soil recovered $(r=0.63$, $P<0.05$ and $0.82, P<0.01$ respectively, Table 2) confirming the results obtained in 1993 at this site.

Table 2. Summary of soil inoculum and disease incidence data for five field trials monitoring impact of aggregate sheath spot disease of rice

\begin{tabular}{|c|c|c|c|c|c|c|c|}
\hline \multirow[b]{2}{*}{ Trial identification } & \multirow[b]{2}{*}{$\begin{array}{l}\text { No. flood basins } \\
\text { surveyed (hec- } \\
\text { tares) }\end{array}$} & \multirow[b]{2}{*}{$\begin{array}{l}\text { No. soil subsamples } \\
\text { and size }\end{array}$} & \multicolumn{2}{|c|}{$\mathrm{K}_{2} \mathrm{CO}_{3}$ assay $\mathrm{PCFE}^{\mathrm{c}}$} & \multicolumn{2}{|c|}{ Water assay WFE $^{d}$} & \multirow[b]{2}{*}{$\begin{array}{l}\text { Range of disease } \\
\text { incidence as \% } \\
\text { (no. tillers) }^{\mathbf{f}}\end{array}$} \\
\hline & & & $\begin{array}{l}\text { Total sclerotia } \\
\text { per gram soil } \\
\quad(r \text { value })^{\mathrm{e}}\end{array}$ & $\begin{array}{l}\text { Viable sclerotia } \\
\text { per gram soil } \\
(r \text { value })^{\mathbf{e}}\end{array}$ & $\begin{array}{l}\text { Total sclerotia } \\
\text { per gram soil } \\
\quad(r \text { value })^{\mathrm{e}}\end{array}$ & $\begin{array}{l}\text { Viable sclerotia } \\
\text { per gram soil } \\
\quad(r \text { value })^{\mathbf{e}}\end{array}$ & \\
\hline \multirow[t]{2}{*}{$\begin{array}{l}\text { Site } 1 \text { (Sutter Co.) } \\
1993\end{array}$} & \multirow[t]{2}{*}{$30(-6.1)$} & $\mathrm{K}_{2} \mathrm{CO}_{3}: 3$ at $50 \mathrm{~g}$ per basin & $\begin{array}{l}0.167-0.580 \\
\quad(0.273)\end{array}$ & $\begin{array}{l}0-0.060 \\
(0.327)\end{array}$ & & & \multirow[t]{2}{*}{$\begin{array}{l}29.1-97.4 \\
(100+)\end{array}$} \\
\hline & & $\mathrm{H}_{2} \mathrm{O}: 2$ at $50 \mathrm{~g}$ per basin & & & $\begin{array}{l}0.113-0.520 \\
\quad(0.234)\end{array}$ & $\begin{array}{l}0-0.120 \\
\left(0.561^{\mathrm{b}}\right)\end{array}$ & \\
\hline \multicolumn{3}{|c|}{ Site 11993 - by cultural practice ( 6 treatments $\times 5$ replications) } & $\begin{array}{l}0.216-0.447 \\
\quad(0.597)\end{array}$ & $\begin{array}{l}0.007-0.041 \\
\quad\left(0.823^{\mathrm{a}}\right)\end{array}$ & $\begin{array}{l}0.172-0.379 \\
\quad\left(0.960^{\mathrm{b}}\right)\end{array}$ & $\begin{array}{l}0.009-0.087 \\
\left(0.917^{\mathrm{b}}\right)\end{array}$ & \multirow{2}{*}{$\begin{array}{l}51.3-82.4 \\
(500+) \\
15.1-78.1 \\
(100+)\end{array}$} \\
\hline Site 11994 & $10(-2.0)$ & $\mathrm{H}_{2} \mathrm{O}: 1$ at $100 \mathrm{~g}$ per basin & n.t $\mathrm{t}^{\mathrm{g}}$ & n.t & $\begin{array}{l}0.21-0.61 \\
\left(0.632^{\mathrm{a}}\right)\end{array}$ & $\begin{array}{c}0.02-0.33 \\
\left(0.820^{\mathrm{b}}\right)\end{array}$ & \\
\hline $\begin{array}{l}\text { Site } 2 \text { (Colusa Co.) } \\
1994\end{array}$ & $11(-7.8)$ & $\begin{array}{l}\mathrm{H}_{2} \mathrm{O} \text {, then } \mathrm{K}_{2} \mathrm{CO}_{3} \text { extraction } \\
\text { of same subsamples: } 3 \text { at } \\
100 \text { g per basin }\end{array}$ & n.d $d^{\text {h }}$ & n.d. & n.d. & n.d. & $\begin{array}{l}1.9-7.9 \\
(300+)\end{array}$ \\
\hline Site 21995 & $5(-3.5)$ & $\mathrm{H}_{2} \mathrm{O}: 3$ at $1.00 \mathrm{~kg}$ per basin & n.t. & n.t. & n.d. & n.d. & $\begin{array}{l}0.6-6.9 \\
(300+)\end{array}$ \\
\hline $\begin{array}{l}\text { Site } 3 \text { (Butte Co.) } \\
1995\end{array}$ & $32(-6.1)$ & $\mathrm{H}_{2} \mathrm{O}: 2$ at $100 \mathrm{~g}$ per basin & n.t. & n.t. & n.t. & $\begin{array}{l}0.020-0.170 \\
\quad(.209)\end{array}$ & $\begin{array}{l}13.9-95.4 \\
(200+)\end{array}$ \\
\hline \multicolumn{3}{|c|}{ Site 31995 - by cultural practice ( 8 treatments $\times 4$ replications) } & n.t. & n.t. & n.t. & $\begin{array}{l}0.071-0.121 \\
\quad(.102)\end{array}$ & $\begin{array}{l}53.3-84.6 \\
(800+)\end{array}$ \\
\hline
\end{tabular}

a Denotes significance at $P<0.05$.

b Denotes significance at $P<0.01$.

c Potassium carbonate flotation extraction.

d Water flotation extraction.

e Correlation values are to disease incidence (last column)

f No. tillers evaluated per data value used in correlations.

g Not tested.

h Not detected. 
Site 2 (Colusa Co., CA) 1994: Sclerotia of Rhizoctonia oryzae-sativae were not recovered by either extraction. The highest incidence of disease observed, nearly $8 \%$, was lower than that observed either year at site 1 . Overall, disease incidence was too low to discern differences between straw management treatments. As aggregate sheath spot disease was observed, and the number of sclerotia per $g$ of soil was apparently very low, subsample size was increased in 1995. Water samples collected from the surface of the basins flooded during the winter of 1994 to 1995 contained a few viable sclerotia of $R$. oryzae-sativae along with sclerotia of Sclerotium hydrophilum Sacc. in Rothert and Sclerotium oryzae Cattaneo. Sclerotia of S. hydrophilum outnumbered those of $R$. oryzaesativae by an estimated ratio of $10^{4}$ to $10^{6}: 1$. Thus, the low level of disease observed in 1994 (Table 2), and the subsequent recovery of $R$. oryzae-sativae sclerotia from the basin following the 1994 crop (data not shown) indicated that neither the PCFE nor the WFE recovery methods were effective when inoculum level was very low, particularly when soil samples were small $(<300 \mathrm{~g})$.

Site 2 (Colusa Co., CA) 1995: The WFE again failed to recover viable sclerotia of $R$. oryzae-sativae despite increasing the subsample size by a factor of 10 (i.e., 3 subsamples of $1 \mathrm{~kg}$ each per basin). Observed disease incidence was lower this year as well.

Site 3 (Butte Co., CA) 1995: Soil inoculum levels determined by WFE did not correlate with disease incidence (Table 2). However, residue management affected inoculum levels (Table 3). Sclerotia collected from these soil samples were often fragmented, unlike those from site 1 . Accurate estimation of total sclerotial counts from sclerotial fragments was not possible. Numerous fragments produced viable cultures. A comparison of germination rates of whole sclerotia versus fragmented sclerotia from samples at site 3 showed high variation (data not presented). Only the sclerotia labeled elsewhere as the viable fraction of sclerotia recovered by WFE (=viable floating sclerotia, VFS, Table 3) could be estimated accurately from a soil sample. In- oculum of $R$. oryzae-sativae in this test was designated as VFS. Disease incidence at site 3 ranged from 14 to $95 \%$ (Table 2). Overall, sclerotial counts at this site averaged 0.347 whole floating sclerotia per $g$ of soil, with a viable fraction of 0.091 VFS per $\mathrm{g}$ of soil (about 1 sclerotia per $11 \mathrm{~g}$ of soil, 22).

The sclerotial inoculum level at site 3 was roughly 5 times greater than that recovered at site 1 in 1993 (0.282 sclerotia floating per $g$ of soil and 0.018 VFS per $g$ of soil, or about 1 sclerotia per $56 \mathrm{~g}$ of soil) where disease incidence similarly ranged from 29 to $97 \%$ (Table 2). It was slightly lower than site 1 in 1994 when inoculum level was 0.111 VFS per $g$ of soil (about 1 sclerotia per $9 \mathrm{~g}$ of soil) and disease incidence ranged from 15 to $78 \%$.

Unlike the results from site 1 , at site 3 no effect of straw residue management practice on disease incidence was noted, although a trend of less disease incidence in basins flooded over the winter was suspected $(56.5 \%$ incidence vs. $80.9 \%$ incidence in the nonflooded basins, 22). Soil inoculum levels were significantly affected by these practices at both sites. Site 1 studies were in their fourth and fifth year and site 3 studies were in their first year. The cumulative effect of repeated annual treatments under study at these sites on inoculum levels and subsequent aggregate sheath spot disease incidence requires further study. The number of VFS recovered at site 3 was significantly higher where straw residue was incorporated into the soil, with an average of 0.119 VFS per $g$ of soil (approximately 1 sclerotia per $8.4 \mathrm{~g}$ of soil) versus lower levels in all other treatments (Table 3).

\section{DISCUSSION}

Results from this study revealed that cultural practices correlated with levels of sclerotial inoculum, but not always with subsequent disease incidence. This suggests initial inoculum is but one factor in the aggregate sheath spot disease cycle contributing to final disease impact. Methods that removed rice straw residue in the fall after harvest, including baling and burning, reduced sclerotia significantly when compared to methods that incorpo- rated the straw into the soil, especially if incorporation was delayed until the following spring (Table 3). Increase in soil contact of the stubble in the fall by disking added the benefit of easier bed preparation (by requiring less spring disking) compared to spring incorporation of stubble, as well as reducing sclerotial inoculum. Disease incidence appeared to be lower, though not significantly (22) after winter flooding at site 3, warranting further research. Effects of winter vetch cover on rice aggregate sheath spot disease incidence and inoculum levels were not detected at site 1 (22).

The methods developed to quantify sclerotial inoculum of $R$. oryzae-sativae in soil (WFE and PCFE) were used to compare inoculum levels as influenced by cultural straw management practices. When applied to rice-field soil samples, the methods provided a measure of differences in soil inoculum levels, proved effective and accurate within their respective limits, and gave insight on the epidemiology of aggregate sheath spot of rice. Limitations of both methods were observed. The WFE method sacrificed knowledge of the role of sclerotia that did not float. These have been shown to be viable (22), and could contribute to root infection (25). The PCFE was developed to detect the influence of sedimented inoculum, and revealed the presence of viable sclerotia in the root zone of the rice plant. This inoculum was not shown to be of significant influence in the epidemiology of aggregate sheath spot in this study. When used together, WFE plus PCFE compromised the viability of those sclerotia recovered from the sedimented residue of a soil sample, so this fraction was not accurately represented. Also, PCFE was time-consuming and required handling caustic materials. Furthermore, results obtained with WFE plus PCFE were not considered more accurate in predicting disease incidence than WFE alone. The less labor required for WFE and data obtained, coupled with the higher correlations with disease incidence observed, favor its use over the combined methods when many samples are required to compare cultural effects upon aggregate sheath spot disease sclerotial inoculum.

Table 3. Mean inoculum levels (sclerotia per g soil) of Rhizoctonia oryzae-sativae as influenced by straw management practices, and mean separations

\begin{tabular}{|c|c|c|c|c|c|c|c|}
\hline \multirow[b]{2}{*}{ Trial identification } & \multirow[b]{2}{*}{$\begin{array}{l}\text { Inoculum } \\
\text { class }^{\mathrm{a}}\end{array}$} & \multirow{2}{*}{$\begin{array}{l}\text { Least significant differ- } \\
\text { ence between treatments } \\
\qquad(P=0.05)^{\mathrm{b}}\end{array}$} & \multicolumn{5}{|c|}{ Straw management practice (treatments) } \\
\hline & & & $\begin{array}{c}\text { Soil incorporation- } \\
\text { spring }\end{array}$ & $\begin{array}{l}\text { Soil incorporation- } \\
\text { fall }\end{array}$ & Burning & $\begin{array}{c}\text { Straw removal- } \\
\text { baling }\end{array}$ & $\begin{array}{l}\text { Straw } \\
\text { rolling }\end{array}$ \\
\hline \multirow[t]{4}{*}{ Site 1 - 1993} & TSK & 0.111 & 0.443 & 0.335 & 0.247 & & \\
\hline & VTSK & 0.018 & 0.033 & 0.012 & 0.010 & & \\
\hline & TSW & 0.097 & 0.368 & 0.281 & 0.198 & & \\
\hline & VTSW & 0.015 & 0.071 & 0.027 & 0.011 & & \\
\hline \multirow{2}{*}{ Site $1-1994$} & TSW & 0.099 & 0.502 & 0.509 & 0.289 & & \\
\hline & VTSW & 0.054 & 0.228 & 0.134 & 0.062 & & \\
\hline Site 3 - 1995 & VFS & 0.026 & & 0.119 & 0.093 & 0.084 & 0.070 \\
\hline
\end{tabular}


Linear correlation of data from field site 1 suggested a basal level of disease incidence would occur when sclerotial inoculum levels were undetectable. This suggested several possibilities: the WFE and PCFE methods were not detecting sclerotial inoculum at very low levels; inoculum existed in other forms (e.g., as hyphal fragments colonizing straw debris and/or basidiospores), or a linear fit was not appropriate. Seedborne inoculum has not been reported, but cannot be discounted without further study because no screening system is in place. The level of detection for the assays described when used in combination was 2 sclerotia in $300 \mathrm{~g}$ of artificially infested soil and 1 viable sclerotia in $100 \mathrm{~g}$ of naturally infested field soil (Table 1).

Although disease incidence ranged from 29 to $97 \%$ at site 1 in the 1993 rice season (Table 2), it is noteworthy that transformation of the incidence data to account for multiple infection (8) only reduced the linear correlation of incidence to inoculum for any recovered class of sclerotia inspected. Close inspection in situ might determine whether multiple infection occurs on individual rice plants at a significant level. Multiple infection transformation of the incidence data from all sites and years surveyed here did not improve the correlations of inoculum to disease.

Also at site 1, correlation of total sclerotia to disease incidence was insignificant, but viable sclerotia recovered by WFE was significantly correlated with disease, and this was even more pronounced when data were analyzed by cultural practice. Together these analyses support the conclusion that the WFE is measuring epidemiologically significant inoculum, suggesting that the inoculum recovered floating on water more directly reflects disease expected to occur in the field.

Detection of very low inoculum levels was problematic. At site 2, despite observed disease incidence as high as $8 \%$, no sclerotial inoculum was detected. This suggests sclerotial inoculum at this site was $<1$ per $300 \mathrm{~g}$ of soil in 1994 and $<1$ per 3,000 $\mathrm{g}$ of soil in 1995. Also, a significant correlation between sclerotial level and disease incidence was not recorded when sclerotial levels were higher (e.g., overall mean of 1 per $8 \mathrm{~g}$ of soil at site 3 ). These results suggest that counts of sclerotial inoculum from the finished seed bed are not adequate to predict subsequent disease by a linear regression, and also that other inoculum forms might contribute to disease incidence. Also, despite obvious treatment effects upon sclerotial inoculum at site 3 (Table 3), no such effects were observed with respect to disease incidence, suggesting that inoculum pressure is only one factor contributing to development of the aggregate sheath spot disease. Similar discrepancies between measured inoculum and subse- quent disease were seen for sheath blight caused by $R$. solani (6).

Future research should include a study on sampling methods to account for the possibility of uneven distribution of sclerotia, uniformity of infection foci in fields, and sample sizes. The interaction of the aggregate sheath spot pathogen with the stem rot pathogen ( $S$. oryzae) and nonpathogenic organisms possibly antagonistic to $R$. oryzae-sativae may also be affecting the results shown here. The difference in soil types between the sites may also affect recovery of sclerotia. Since much California rice land is effectively continuous, i.e., not rotated with other crops, the cumulative effect over years of repeated cultural treatments under study at these sites on inoculum levels and subsequent aggregate sheath spot disease incidence requires further study.

More definitive information is also needed regarding the role of basidiospores or hyphal fragments in straw residue in the disease cycle of aggregate sheath spot. Even though initial symptoms of aggregate sheath spot appear at the waterline in basins, this does not exclude the possibility that hyphal fragments play a role in disease incidence observed in the field. Results to date do not exclude the possibility that both hyphal fragments and sclerotia may constitute sources of primary inoculum. Also, the teleomorph of $R$. oryzae-sativae was observed by Gunnell (9) in the field. Thus, basidiospores as secondary inoculum may be contributing to observed disease incidence, especially when data are collected late in the rice-growing season.

These observations of soil inoculum levels and subsequent disease incidence add to reports on the epidemiology of aggregate sheath spot disease $(9-15,17,18,24,26)$. In California rice production, $R$. oryzaesativae produces sclerotia on an annual cycle with the crop. Other sclerotial pathogens of rice (e.g., S. oryzae, R. solani) behave similarly in sclerotial production.

In summary, recovery methods shown to be accurate and efficacious in detecting low levels of sclerotia of the rice aggregate sheath spot pathogen showed strong influence of cultural rice straw management practices on this inoculum source, but at the same time revealed the seedbed sclerotial inoculum levels did not predict subsequent disease incidence as the rice crop developed. Of the sclerotia in the seedbed, those that floated to the surface of the paddy showed the highest correlations to subsequent disease, reinforcing the understanding of the mechanical epidemiology surrounding these sclerotia as primary inoculum at the waterline. Cultural practices that removed rice straw from the flood basins after harvest showed the greatest effect in reducing sclerotial inoculum. Further study is needed to identify cultural practices to reduce disease incidence and development.
LITERATURE CITED

1. Ben-Yephet, Y., and Pinkas, Y. 1976. A cesium chloride flotation technique for the isolation of Verticillium dahliae microsclerotia from soil. Phytopathology 66:1252-1254.

2. Boosalis, M. G., and Scharen, A. L. 1959. Methods for microscopic detection of Aphanomyces euteiches and Rhizoctonia solani and for isolation of Rhizoctonia solani associated with plant debris. Phytopathology 49:192-198.

3. Buhler, D. D., and Maxwell, B. D. 1993. Seed separation and enumeration from soil using $\mathrm{K}_{2} \mathrm{CO}_{3}$-centrifugation and image analysis. Weed Sci. 41:298-302.

4. Castro, C., Davis, J. R., and Wiese, M. V. 1988. Quantitative estimation of Rhizoctonia solani AG-3 in soil. Phytopathology 78:12871292.

5. Clark, C. A., Sasser, J. N. and Barker, K. R. 1978. Elutriation procedures for quantitative assay of soils for Rhizoctonia solani. Phytopathology 68:1234-1236.

6. Damicone, J. P., Patel, M. V., and Moore, W. F. 1993. Density of sclerotia of Rhizoctonia solani and incidence of sheath blight in rice fields in Mississippi. Plant Dis. 77:257-260.

7. Gangopadhyay, S., and Grover, R. K. 1985. A selective medium for isolating Rhizoctonia solani from soil. Ann. Appl. Biol. 106:405412.

8. Gregory, P. H. 1948. The multiple-infection transformation. Ann. Appl. Biol. 35:412-417.

9. Gunnell, P. S. 1986. Characterization of the teleomorphs of Rhizoctonia oryzae-sativae, Rhizoctonia oryzae, and Rhizoctonia zeae, and the effect of cultural practices on aggregate sheath spot of rice, caused by $R$. oryzaesativae. Ph.D. diss. University of California, Davis.

10. Gunnell, P. S., and Webster, R. K. 1984. Aggregate sheath spot of rice in California. Plant Dis. 68:529-531.

11. Inagaki, K. 1993. Annual changes in outbreak of rice sclerotial diseases caused by Rhizoctonia and Sclerotium spp. in paddy fields. Proc. Kansai Plant Prot. 35:13-18.

12. Inagaki, K., and Isomura, Y. 1992. Survival durations of Sclerotium oryzae-sativa Sawada strains in paddy fields and their distribution in a neighboring field. Ann. Phytopathol. Soc. Jpn. 58:340-346.

13. Kadowaki, Y., and Isota, J. 1993. Ecology of sclerotial diseases of rice. Part 1. Seasonal changes in the distribution of sclerotial fungi in paddy fields. Ann. Phytopathol. Soc. Jpn. 59:681-687.

14. Kadowaki, Y., and Isota, J. 1993. Ecology of sclerotial diseases of rice. Part 2. Time and location of isolation. Ann. Phytopathol. Soc. Jpn. 59:688-693.

15. Kadowaki, Y., Isota, J., and Tsukamoto, T. 1995. Ecology of sclerotial diseases of rice. Part 3. Distribution of several sclerotial fung causing sclerotiosis in rice. Ann. Phytopathol. Soc. Jpn. 61:63-68

16. Kataria, H. R., and Gisi, U. 1989. Recovery from soil and sensitivity to fungicides of Rhizoctonia cerealis and R. solani. Mycol. Res. 92:458-462.

17. Kim, W. G. 1993. Morphological and cultural characteristics of fungi causing rice sclerotial diseases. Korean J. Mycol. 21:16-22.

18. Kim, W. G., and Ishii, K. 1992. Lesion and sclerotial formation and penetration of sclerotial fungi on rice plants. Res. Rep. RDA (C. P.) 34:7-11

19. Ko, W., and Hora, F. K. 1971. A selective medium for the quantitative determination of Rhizoctonia solani in soil. Phytopathology 61:707-710.

20. Krause, R. A., and Webster, R. K. 1972. Sclerotial production, viability determination and 
quantitative recovery of Sclerotium oryzae from soil. Mycologia 64:1333-1337.

21. Leach, L. D., and Davey, A. E. 1938. Determining the sclerotial population of Sclerotium rolfsii by soil analysis and predicting losses of sugar beets on the basis of these analyses. J. Agric. Res. 56:619-631.

22. Miller, T. C. 1996. A method for recovering sclerotia of the fungal pathogen Rhizoctonia oryzae-sativae from rice field soils. M.S. thesis. University of California, Davis.

23. Miller, T. C., and Webster, R. K. 1996. Recovery of sclerotia of Rhizoctonia oryzaesativae and determination of inoculum of aggregate sheath spot disease from rice field soils. (Abstr.) Phytopathology 86:S111.

24. Moletti, M. 1992. Attacchi del fungo Rhizoctonia oryzae-sativae sul riso in Italia. Inf. Fitopatol. 3:11-14.

25. Mordue, J. E. M. 1974. Rhizoctonia oryzaesativae. C.M.I. 409.

26. Pan S., and Islam, S. J. 1991. Effect of soil moisture and soil amendment on survival of sclerotia of Rhizoctonia oryzae-sativae. J.
Mycopathol. Res. 29:77-82.

27. Rodriguez-Kabana, R., Backman, P. A., and Wiggins, E. A. 1974. Determination of sclerotial populations of Sclerotium rolfsii in soil by a rapid flotation-sieving technique. Phytopathology 64:610-615.

28. Rogers, C. H. 1936. Apparatus and procedure for separating cotton root rot sclerotia from soil samples. J. Agric. Res. 52:73-79.

29. Sneh, B., Burpee, L., and Ogoshi, A. 1991. Identification of Rhizoctonia Species. American Phytopathological Society, St. Paul, MN.

30. Steel, R. G. D., and Torrie, J. H. 1980. Principles and Procedures of Statistics. 2nd ed. McGraw-Hill, San Francisco.

31. Trujillo, E. E., Cavin, C. A., Aragaki, M., and Yoshimura, M. A. 1987. Ethanol-potassium nitrate medium for enumerating Rhizoctonia solani-like fungi from soil. Plant Dis. 71:1098-1100.

32. Ui, T., Naiki, T., and Akimoto, M. 1976. A sieving-floatation technique using hydrogen peroxide solution for determination of sclerotial population of Rhizoctonia solani Kühn in soil. Ann. Phytopathol. Soc. Jpn. 42:46-48.

33. Utkhede, R. S., and Rahe, J. E. 1979. Wetsieving floatation technique for isolation of sclerotia of Sclerotium cepivorum from muck soil. Phytopathology 69:295-297.

34. Van Bruggen, A. H. C., and Arneson, P. A 1986. Quantitative recovery of Rhizoctonia solani from soil. Plant Dis. 70:320-323.

35. Vincelli, P. C., and Beaupré, C. M.-S. 1989. Comparison of media for isolating Rhizoctonia solani from soil. Plant Dis. 73:10141017.

36. Webster, R. K., and Gunnell, P. S., eds. 1992. Compendium of Rice Diseases. American Phytopathological Society, St. Paul, MN.

37. Webster, R. K., Wick, C. M., Brandon, D. M. Hall, D. H., and Bolstad, J. 1981. Epidemiology of stem rot disease of rice. Effects of burning vs. soil incorporation of rice residue. Hilgardia 49:1-12.

38. Weinhold, A. R. 1977. Population of Rhizoctonia solani in agricultural soils determined by a screening procedure. Phytopathology 67:566-569. 